\section{AUTRAN DE LEITORES E} LEITORES

DOURADO, Autran. Um cavalheiro de antigamente. São Paulo: Siciliano, 1992.

A obra de Autran Dourado, composta de mais de vinte volumes de romances, novelas $\mathrm{e}$ contos, publicados desde os anos 50 , tem sido sempre objeto de pesquisas inquietas e inquietantes nas universidades brasileiras. Merece citação, por exemplo, o trabalho de Angela Senra, Paixão e fé, recentemente editado pela UFMG, por constituir um corajoso exercício de interpretação, personalizada ao máximo, quase personalista, mas capaz de fazer seu leitor encantado cismar nas histórias de Minas e dele mesmo, nos nossos novelários sem fim.

Sobre Autran, Angela se pergunta, com Foucault, se "narrar não seria sempre uma busca das origens". Afinal, é o que parece fazer $o$ autor mineiro em toda a sua obra, inclusive em seu romance mais novo, Um cavalheiro de antigamente .Trata-se da última história de uma trilogia iniciada por Ópera dos mortos (1967), e continuada com Lucas Procópio (1984), passando por três gerações de uma familia mineira, em toda a sua imponência, sofrimento e loucura. A neta, Rosalina, seu avô,
Lucas Procópio, por fim, o elo que faltava, filho/pai, João Capistrano, protagonizam as histórias, cada um recontando o outro, com muito amor e ódio.

As estratégias narrativas de Autran Dourado passam pelo fluxo de consciência, pela pluralidade de focalizações, capazes de criar em profundeza caleidoscópica as individualidades, como diferentes vozes ficcionais. Entretanto, seu maior mérito não se resume à representação das solitudes, dos conflitos íntimos, pessoais e intransferiveis: funde-se a isso, ao inconsciente, toda a construção da cidade, da vida coletiva, que integra o drama com as desavenças e amizades, com as profissões e poderes. A rua, a venda, a igreja, transformam-se também em personagens dessa história social de Minas Gerais que Autran apresenta aos poucos a seus leitores. Cada narrativa é simultaneamente nova e antiga, o ambiente da trama nos parece familiar e inusitado ao mesmo tempo: Tinha de ser mesmo demorada essa grande tarefa do escritor mineiro: pósouro, pós-tudo, os coronéis de Minas se multiplicam em fragilidades e violências impensáveis, enquanto as mulheres sofrem, rezam, transam e traçam destinos no dia a dia. É toda uma terra e toda uma sociedade que assim vai-se construindo, num texto denso, manhoso e maduro.

Esta mais recente obra de $\mathrm{Au}-$ tran Dourado ainda espera leitu- ras apaixonadas e inteligentes, como a que fez Angela Senra d'Os sinos da agonia, ou Eneida Maria de Souza d'A barca dos homens. Aparecem, já, na imprensa, comentários sobre Um cavalheiro de antigamente. Todos têm a leveza, brevidade e clareza típicas dos textos jornalísticos. Um deles, entretanto, apresenta tantos ataques a tantos bons ficcionistas brasileiros que não pode passar impunemente por leitores que, como eu, sejam estudiosos de literatura: trata-se da resenha de Marilene Felinto, que se fez presente na Folha de São Paulo, no dia 24/03/93, para demonstrar que "Dourado produz romance antigo".

De início, Felinto arrola vários escritores sob a pecha de "expoentes vivos da literatura brasileira oficial": Autran Dourado, J. J. Veiga, Ligia Fagundes Telles, Rubem Fonseca, Fernando Sabino, etc (sic). Ora, sabemos que, quando o termo "oficial" se transforma em pecha na crítica literária, está utilizado num contexto de defesa das contraliteraturas ou paraliteraturas. Felinto, todavia, paradoxalmente, usa-o para defender uma nova e superior literatura de mercado, em nome de jovens leitores brasileiros que teriam horror ao "mofo", ao "antigo", logo, ao "oficial". Em si mesma, a defesa da literatura de mercado nada tem de vergonhoso, como a faz José Paulo Paes, por exemplo, ao clamar por maior produção de escritores profissi- 
onais, voltados para um público-leitor com enorme potencial de expansão no Brasil. Mas, daí a tentar destruir a validade lite-

rária da produção ficcional de uma geração inteira, apenas porque os adolescentes a detestam, vai uma distância enorme. $\mathrm{E}$, ainda, para agravar o caráter preconceituoso da resenha, Felinto nem se digna explicar a presença, em sua lista negra, de autores de best-sellers, como Rubem Fonseca e Fernando Sabino.

Outra generalização pejorativa de Felinto, que igualmente se mostra insustentável, diz respeito aos "mestres" dos ficcionistas citados: todos eles, sem exceção, se inspirariam no Mário de Andrade prosador, e, também, no Machado cronista. Como nem esses improváveis "mestres" são poupados pela articulista, resta aos leitores da Folha lamentar que se lide assim com a tradição literária brasileira, tentando destruir o que pouco se conhece.

Certa vez afirmei que a história da leitura é essencialmente faltosa, porque nenhum leitor leu todos os textos, assim como nenhum texto foi escrito para todos os leitores. Porém, mesmo sem a pretensão de ter lido tudo, cabe ao crítico ler o suficiente para instaurar sua fala num horizonte cultural mais amplo, em que seus próprios leitores se reconheçam e se identifiquem. Nesse ponto, pelo menos, a tão "oficial" crítica universitária ganha em coerên- cia da jomalística: afinal, quais leitores da Folha de fato considerariam Mário de Andrade tão "ruim", Machado tão "superficial", e romancistas contemporâneos como Autran Dourado ou Lígia Fagundes Telles tão "apagados"?

Após esses equívocos lamentáveis, só nos consola saber que a nova obra de Autran Dourado acabará merecendo a atenção de seus verdadeiros leitores virtuais: aqueles amantes do jogo de renovação e tradição, como bons conhecedores dessa grande arte, a literatura, que caminha por "ruas capistranas de toda cor".

\section{ESCRITAS SUPERPOSTAS}

ARÊAS, Vilma. A terceira perna. São Paulo: Brasiliense, 1992.

A escrita mosaico de Vilma Arêas, em A terceira perna, finca alicerce em sofisticado arcabouço teórico, sob a chancela especial da paródia e citação. Especialistas em teoria literária (a própria autora leciona essa matéria na UNICAMP) poderiam citar, ainda, inúmeros outros recursos subsidiários (tais como a intertextualidade, o mise en abyme, a ironia, a alegoria, o fragmento, o relato epistolar, o foco especular, etc.). A partir da metáfora do título - uma terceira perna para voar? indaga a epígrafe-prefácio de Brecht o texto se desvencilha de amarras seculares e instaura um carnavalizado processo de anulação de fronteiras entre o narrativo e o descritivo, entre o relato e o fragmento lírico, entre o ensaio e a crônica. Esta escrita sobre outra escrita, terreno escorregadio onde muitos "rasgam sedas e treinam a medida justa da frivolidade" (p.28), possibilita a criação de uma terceira via de acesso ao invisível: o texto reinventado. Para tanto é preciso acolher a tradição ("as palavras de costume"), acoplar teoria e práxis, círculos e espelhos em (simultânea) interação. Daí que os textos "só podem crescer em círculos" (p.71) e os amantes de "Romeu e Julieta nas águas (furtadas)", embora saibam "que os pássaros devoram as migalhas largadas pelos caminhos e, com sua fome, inventam o labirinto" ... "desejam também a originalidade." (p.74) Ainda que às vezes tendente ao excesso e à retórica, o texto antes se posiciona como espaço de reflexão sobre si mesmo, a um só tempo assumido como ofício lúdico e especular. Aberto ao diálogo e à apropriação de traços de outras linguagens como construção de imagens - cinema, fotografia, pintura. Vejam-se, a propósito, o monumental travelling de "Gruppo de famiglia" e textos como 